\title{
La imagen sometida. Ideología y contraideología de la representación visual en el cine digital y de animación latinoamericano
}

\author{
Forced Image. Ideology and counter-ideology \\ of visual representation in Latinamerican \\ digital cinema and animation
}

\author{
Samuel Viñolo Locuviche \\ Universitat de Barcelona, España \\ jvinollo7.alumnes@ub.edu
}

\author{
Fernando Infante del Rosal \\ Universidad de Sevilla, España \\ finfante@us.es
}

- Resumen - Aunque sigue pensándose que el poder fomenta, mediante el desarrollo tecnológico, el uso de la imagen como herramienta de dominio, la evolución de las imágenes parece apuntar hacia otro lugar: la imagen sintética se ha convertido en un fin en sí misma. A las sociedades desarrolladas industrialmente no les interesa tanto el dominar con la imagen como dominar la imagen misma, porque este dominio es el síntoma más notorio de una sociedad avanzada. Aunque el cine de animación digital, avanzadilla de la tecnología digital, constituye el medio adecuado para ese sometimiento de la imagen por parte de la industria predominante, han surgido movimientos que oponen resistencia a este modelo. Este artículo analiza cómo actúa esta resistencia en el contexto de la animación latinoamericana.

Palabras clave: tecnología digital, cine digital, cine de animación, América Latina, teoría del cine.

Abstract - It is still thought that power authorities promote the use of images through technological development as a tool for social control and domination. Nonetheless, the evolution of image seems to point another way, in which generation of synthetic images becomes its own purpose: industrially developed societies are less interested in control through images than mastering image generation, because this is the most obvious sign of a technologically advanced society. Although digital animation, vanguard of digital technology, seems now the most appropriate way to master image production, many dissident groups has arisen to oppose this standardized models. This paper analyzes how these oppositional forces act within latin american animation in a special way.

Keywords: Digital technology, digital film, animation film, Latin America, Film Theory. 
Durante todo el siglo $\mathrm{xx}$, y desde una crítica cultural interesada por los nuevos procesos de generación de imágenes, se ha proyectado la idea de que las sociedades con desarrollo tecnológico han ido conquistando de manera progresiva nuevos aspectos de la imagen como herramienta de dominio: el perfeccionamiento de las imágenes ha sido concebido por esta crítica como medio básico de confabulación contra la realidad. El desarrollo actual de las imágenes parece apuntar, en cambio, hacia otro lugar: la imagen construida se ha transformado en un fin en sí misma. A estas sociedades desarrolladas industrialmente no les interesa tanto el dominar con la imagen como dominar la imagen misma. La hipertrofia figurativa y perceptiva de las representaciones visuales se ha convertido en la credencial del nuevo progreso. Así, la imagen sometida se presenta hoy como el símbolo más pregnante y sintético de una sociedad avanzada.

Esto es claramente observable en la evolución del cine desde los años noventa. En esta década, el perfeccionamiento en la construcción de la imagen se convierte en el rasgo más característico de los cines hegemónicos, no solo en los aspectos que proceden del uso de la tecnología, sino en la capacidad para controlar hasta el más leve elemento de los que se integran dentro de esa representación, como se aprecia en la importancia de la dirección artística y de producción desde esos años. La prodigiosa evolución de los efectos digitales, por su parte, ha hecho posible que esta conquista de la imagen sea absoluta. Y esto se termina manifestando en el encumbramiento popular del nuevo cine de animación y de los medios más recientes de imagen tridimensional y realidad aumentada.

Es de esperar que en este nuevo dominio sobre la representación y el fantasma, la creatividad y la capacidad artística terminen siendo más relevantes que los medios tecnológicos, por cuanto estos se abaratan progresivamente y empiezan a estar al alcance de sociedades que no poseen la hegemonía tecnológica, si bien no es la tendencia actual. Y sucede también que, desde determinados ámbitos, ese poder sobre la imagen es percibido como ideología a la que se opone una contraideología que opta por volver a una estética de la imperfección. En América Latina se enfrentan ambas tendencias, haciendo que el contraste en su producción de imágenes sea mucho mayor que el de otras regiones del mundo y que la identidad latinoamericana se vea forzada a resolverse en una dialéctica indigesta de ideologías.

\section{ACERCAMIENTO A LA RELACIÓN ENTRE IMAGEN E IDEOLOGÍA EN LA CULTURA DE LA REPRESENTACIÓN}

«La vida entera de las sociedades en las que imperan las condiciones de producción modernas se anuncia como una inmensa acumulación de espectáculos. Todo lo directamente experimentado se ha convertido en una representación» (Debord 37). El conocido comienzo de La sociedad del espectáculo, que Debord proclama como consumación moderna de la intuición feuerbachiana, no se ha conformado aún 
completamente. No ha encontrado una forma estable porque, precisamente, el reino de la nueva representación, de la imagen sintética generada tecnológicamente, es siempre un interregno. Como la novedad, también la imagen está abocada a repetirse superándose, yendo siempre más allá de sí misma, abandonando la tierra al momento de conquistarla, pues, como lo nuevo, la imagen sometida también es un síntoma de la dinámica del capitalismo avanzado, una de sus más esforzadas categorías. Cuando la imagen alcanza el fulgor que se le reclama, muere. De ella podríamos decir lo que afirmó Adorno de lo nuevo, que «es hermana de la muerte» (36).

Por esta razón, cualquier análisis del estatuto de las imágenes en la actualidad está abocado a una pronta caducidad, a convertirse rápidamente en relato histórico. El desarrollo tecnológico es el que permite y fomenta esta fugacidad de la imagen y de cualquier intento de asirla; por eso, para alcanzar a la imagen en su constante permutación es necesario asumir el momento tecnológico en sus registros tópicos, dinámicos y económicos (términos que tomamos del psicoanálisis con sentidos diferentes). Aquí intentaremos describir algunos de los rasgos de la producción de imágenes en la actualidad para analizar más de cerca el giro que anunciábamos al principio, desde la imagen como herramienta de dominio a la imagen como objeto de dominio, desde la imagen dominadora a la imagen sometida. Para ello es preciso apuntar siquiera algunos de los rasgos de la primera y avanzar desde allí a nuestra idea, que aplicaremos, en último término, al cine de animación latinoamericano y a su integración en la era digital.

A lo largo de la historia, la retórica del poder ha sido con frecuencia muy consciente de la importancia de las imágenes. Basta un fugaz oteo por la historia del arte para intuir los estrechos vínculos que se han establecido entre la creación de imágenes y los centros de poder. Pero lo que diferencia a este poder de todo contrapoder, de toda contracultura -que también ha generado, y con más ahínco, sus imágenes-, es el interés por controlar los medios humanos y técnicos que producen tales representaciones. En este aspecto, todos los poderes se muestran sorprendentemente simétricos y un análisis de la imagen de tales poderes -y de sus contrapoderes- desvela una escenografía común. "De la teatralización de la política -dice Arnau Roselló-, al poder de representación de la máscara (persona), las relaciones de poder están literalmente atravesadas por la imagen» (3).

La proliferación de los medios y canales de la opinión pública desde el siglo XVIII permite a las imágenes encontrar nuevas vías, más efímeras, pero también más ágiles y próximas, para servir de herramienta de control ideológico aunque, al mismo tiempo, estos cauces les facilitan el soporte para una crítica a este mismo control. La progresiva democratización y socialización de la imagen hace que los medios del poder y de la resistencia converjan, si no en su alcance, sí al menos en su capacidad creativa. En el siglo XIX es posible localizar con mayor amplitud una estética de la resistencia marcada por una factura descuidada, imperfecta, por una impronta ágil y desdeñosa, por un evidente feísmo que marcará gran parte de las 
imágenes de resistencia del siglo xx (aunque no todas). Esta contraestética alcanza el punto del cliché en todos aquellos cines que se han alzado conscientemente contra la factura de buen objeto del cine norteamericano. Cierta imperfección provocada es asociada, desde entonces y en contextos muy dispares, a las posiciones marginales y alternativas a los centros de poder institucionales. La larga historia de la caricatura y el cartelismo satíricos se encuentra en la base de esta asociación entre crítica e imperfección provocada. Cuando nacen los dos medios realistas de producción de imágenes, la fotografía y el cine, su influencia se hace patente en los usos prorevolucionarios de estas, como sucede en los cineastas soviéticos de vanguardia, que, aun buscando la perfección de la imagen en su encuadre, le negaban su absoluto lirismo burgués abatiéndola con un montaje tan perceptible como la propia imagen.

Durante la década de 1940, especialmente durante la Segunda Guerra Mundial, el cine se convierte en un elemento más del combate internacional, y tanto el soviético, como el cine del nazismo o de las tropas aliadas, invertirán notables esfuerzos en producir panfletos cinematográficos cercanos al ámbito del documentalismo. Es precisamente este rasgo documentalista el que empieza a asociarse a los cines de resistencia, como segundo cliché de toda estética alternativa o contraideológica, como sucede en el cinema vérité y en gran parte de los nuevos cines de los años cincuenta.

A pesar de todo, el cine panfletario e ideológico no siempre consiguió convencer con el recurso a las formas del documental, sino dentro de un marco social controlado y objetivizado. Como afirmó Bazin a propósito de El triunfo de la voluntad, el hecho de que este filme tenga "para el espectador democrático el valor de un argumento contra Hitler» (80) pone en entredicho el pretendido cariz manipulador de la imagen y del cine. Si la propia retórica visual del nazismo puede ser utilizada como un contraargumento ideológico por parte de tendencias ideológicas opuestas, se infiere que esa imagen, y quizás cualquier imagen, no posee un poder de convicción absoluto, y que solo alcanzará a sus adeptos o a aquellos que se encuentren encerrados en un cerco de simpatía provocado. Podría llegar a pensarse, incluso, que lo que Bazin sugiere es la posibilidad de rebatir cualquier planteamiento cinematográfico persuasivo a partir de su propia retórica, como si toda imagen implicara inevitablemente su contrario. Tanto si se entiende en un sentido como en el otro, lo cierto es que el comentario de Bazin matiza el valor absoluto del poder de las imágenes en este tiempo. Como escribe Lazo:

Los grupos culturales son capaces de actos interpretativos y con cierto margen importante de libertad. Que estos grupos no son objeto de una homogeneización y manipulación totales, ni siquiera cuando son objeto de una vigilancia y disciplina panópticas, es decir, ni siquiera en una sociedad con un despliegue tan especializado en sus dispositivos y tecnologías de represión, tal como lo describirían H. Marcuse [...] o Foucault (57).

En la década de 1960, la contracultura se propaga en el momento de eclosión de las industrias culturales. Sus imágenes se apropian de la hipertrofia sensorial de 
las nuevas imágenes de consumo adoptando, en muchas estéticas de resistencia, su mismo carácter visionario y colorista. Ideología y contraideología se enfrentan a un juego de trasvases estéticos que no se había producido nunca antes, como se manifiesta en la doble dirección del détournement y de la récupération que señalaron los situacionistas y que afecta tanto a las imágenes del poder -ahora industrial, tecnológico, económico y mediático-, como a las de la resistencia. Las ideas de Debord y Althusser, y más tarde la relectura de Adorno y Horkheimer por un lado, y de Brecht por otro, terminaron calando entre los cineastas vinculados a los movimientos de izquierdas a ambos lados del Atlántico, en especial en movimientos como el Neues Deutsches Kino en Alemania, el Giovane Cinema en Italia, el New American Cinema en Estados Unidos, y, en América Latina, en el Tercer Cine argentino, en el Cinema Nuovo de Brasil, o en la Nueva Ola en México (Stam 158-67). Como veremos más adelante, esta percepción continúa estando presente en el continente latinoamericano.

En los años setenta, este fervor posrevolucionario se disuelve en las visiones particulares de los autores, emancipados ya de todo grupo ideológico y estilístico. Al mismo tiempo, el malestar de la sociedad norteamericana tras la guerra de Vietnam y el escándalo Watergate empieza a reflejarse en toda la extensión del cine estadounidense, tanto en un nuevo cine crítico de carácter independiente como en el cine espectacular más definitorio de la década: el de catástrofes. Este rasgo favorece un insólito y breve parentesco entre el cine hegemónico y los llamados, desde entonces, cines periféricos. A partir de este momento, las imágenes de resistencia se manifestarán más abiertamente como imágenes formales, evidenciando las fases de estereotipación que hemos descrito. El hecho de que el propio cine de Hollywood pueda recurrir a tales estereotipos parece mancillar la autenticidad que las imágenes de resistencia procuraban. Además, la integración de estas en aquel consolida aún más la asociación entre la imagen de resistencia y los clichés de la imperfección y el aire documental: solo los centros de poder poseen la capacidad de convertir en canónicas tales asociaciones.

En el ámbito de la reflexión cinematográfica, la hegemonía de las teorías posestructuralistas inaugura una etapa más interesada en los aspectos textuales que de contenido y, más adelante, durante la década de 1980, con la aparición de los Cultural Studies, la reflexión sobre el cine se abre a nuevos campos transfronterizos, en los que este ya no es considerado el centro exclusivo de atención. La percepción de la imagen fílmica como herramienta de control ideológico persiste dentro de la teoría cinematográfica, especialmente dentro de los análisis de la Feminist Film Theory, pero, en términos generales, esa percepción se diluye en el análisis de los media. De alguna manera, estos cambios no son ajenos a la implantación progresiva de las nuevas tecnologías en los procesos de producción y exhibición del cine; más bien al contrario, pueden considerarse una consecuencia natural de la transformación profunda de la visión y los hábitos del cine que tiene lugar en las dos últimas décadas del siglo $\mathrm{xx}$. 


\section{DE LA IMAGEN SAGRADA A LA IMAGEN DOMESTICADA}

En este análisis de la transición desde la imagen dominadora a la imagen sometida es preciso tener en cuenta una consideración crucial: el cine no es solo imagen (ya sea visual o sonora), ni siquiera la expresión «imagen en movimiento» define el hecho cinematográfico en su esencia. El cine, como fenómeno y como institución, es principalmente estructura y aparato, implica una serie de procesos síquicos y sociales que atañen a la imagen, pero también a otros elementos como el montaje, la estructura, etc. Enfrentarse al cine desde una teoría de la imagen supone una reducción excesiva de sus márgenes y de su funcionamiento. Lo que sucede en el acto cinematográfico es mucho más que una asimilación de imágenes, el cine es un arte mental (Münsterberg) y afecta al entendimiento y a la afectividad en todos sus niveles. El proceso por el cual unos generadores de formas y contenidos elaboran, dentro de un sistema cultural, económico, industrial y social, y según unos códigos basados en la comprensión y la percepción humanas, un esquema mediante imágenes y sonidos que debe ser actualizado a la manera de una vivencia por un receptor inserto en un contexto intencional es algo suficientemente complejo como para que se intente abarcarlo desde una teoría de la imagen.

El análisis cinematográfico no se agota, pues, en un análisis de las imágenes. Es preciso considerar los aspectos dramáticos y narrativos y, especialmente, aquellos que atañen a la psicología del receptor: los fenómenos de la participación cognitivoafectiva y de la identificación psíquica. Resulta, por ello, imprescindible observar aquello que sucede, no solo detrás de las imágenes, sino también entre ellas. Es en los espacios invisibles del corte entre imágenes, del corte del montaje, en el intersticio, donde se halla una de las diferencias específicas de este medio.

Además, la historia del cine se integra de una manera tan especial en la estructura y el funcionamiento del cine mismo, que no es posible acceder a una comprensión del fenómeno cinematográfico si solo se tiene en cuenta su desarrollo reciente en la era audiovisual. Efectivamente, el cine existió, se consolidó como forma y como industria, y fue incluso canonizado en eso que llamamos cine clásico, mucho antes de que se instalara a sus anchas la cultura audiovisual. Esto es así hasta tal punto que, incluso en su disolución o difuminado en la iconosfera mediática, el cine sigue conservando un cierto vestigio del carácter sagrado con el que se vistiera durante largo tiempo; sigue llamándose «cine», término que atesora todavía la huella del mito y que evoca un borroso pero persistente pasado. La propia cultura audiovisual poscinematográfica fomenta la permanencia de ese pasado canónico educando a las nuevas generaciones en su observancia. Esta autorreferencialidad de la cultura audiovisual, aun en las formas de la ironía y el humor, retiene los valores clásicos de la imagen cinematográfica en el contexto de la imagen desacralizada.

Es preciso, por tanto, acceder al estudio del cine considerando estos dos asuntos: su complejidad como estructura-aparato destinada a una recepción compleja, y sus vestigios como modo de representación institucionalizada en la era de la mirada saturada. 
En la trasformación del cine y en su progresiva desacralización concurren factores industriales, tecnológicos, sociales y culturales que han hecho que la creación y la recepción tengan que buscar nuevos acoples con bastante frecuencia (también puede defenderse lo inverso: que la creación y la percepción determinan o motivan aquellos factores, como podría leerse en Benjamin). La Ferla (20-2) recoge la idea ampliamente asumida de que la aparición de los dispositivos de grabación y reproducción videográficos y digitales supone una ruptura tan radical en la percepción cinematográfica respecto a épocas pasadas, que el cine no puede ya entenderse de la misma forma. En el lado del espectador, formatos como el videocasete, el Laser Disc o el DVD, permiten posibilidades de manipulación anteriormente impensables en la moviola, como la pausa o el salto selectivo de secuencias, que convierten el visionado de una película, en palabras de Dominique Païni, en una experiencia «no lineal y discreta [...] que adapta y pervierte su ontología» (cit. en La Ferla 19). Por otra parte, desde el lado de la producción, la revolución que supone el uso de las nuevas cámaras digitales es aún mayor, ya que cambia la forma de encuadrar: el cineasta puede utilizar los dos ojos en vez de uno, o mirar a través del dispositivo de la cámara o del monitor de vídeo directamente, sin esperar al revelado de la película. Al desaparecer el acto del revelado, pierden valor también otros elementos esenciales en la producción de un filme, como son los antiguos tiempos de preparación de las tomas o el condicionamiento impuesto por la limitación de metraje. Todas estas mutaciones son fácilmente observables en filmes tan dispares como No Quarto do Vanda (Pedro Costa, Portugal, Alemania, Suiza, Italia, 2000), Gerry (Gus Van Sant, Estados Unidos, 2002), Celebración (Festen, Thomas Vinterberg, Dinamarca, 1998), El arca rusa (Russkiy kovcheg, Aleksandr Sokurov, Rusia, 2002) o Inland Empire (David Lynch, Estados Unidos, Polonia, Francia, 2006). En todos ellos, los cambios tecnológicos derivados de la grabación digital terminan afectando a aspectos de la escritura fílmica, como el encuadre, la iluminación o la propia interpretación de los actores.

Junto a estos factores se localizan aquellos otros, más amplios, que proceden de las grandes transformaciones de la industria cinematográfica, especialmente de la norteamericana, desde finales de los años cincuenta a la actualidad. La reconversión de las antiguas majors o su asimilación por grandes compañías multimedia interesadas en la concentración horizontal y, en gran parte de los casos, con empresas matrices ajenas al cine y a la producción cultural, contribuyó a que el cine se convirtiera en una más de las piezas de un sistema de producción y consumo y a que la imagen cinematográfica se diluyera entre el resto de imágenes en la ideología postfordista de la sinergia.

Todos estos elementos están en la base de la actual tendencia al sometimiento de la imagen, al dominio absoluto de las formas de representación y al control sobre toda plasmación fantasmática y visual. La industria, la tecnología y el consumo se han terminado compenetrando hasta tal punto con los nuevos comportamientos y la nueva psicología -o los han determinado tanto-, que unos y otros se conectan al margen de toda alusión externa, al margen de lo real. Lo tecnológico y lo psíquico 
manifiestan en la actualidad un acople tan exitoso, que la referencia a la realidad parece ser solo un medio o una excusa para consumar su complot. El espectador se jacta de un dominio ejercido, no ya sobre la realidad, que ha quedado al margen como mero ingrediente, sino sobre la potencia de representación. Se trata de una especie de poder sobre el poder, de secreta venganza sobre la imagen, que se presenta hace tiempo como un gran panel que impide ver más allá de ella. La imagen, categoría del mundo moderno, arma de control y de conquista, se instala paradójicamente como parapeto que nos bloquea el acceso a todo aquello que no posee una imagen. Por esta razón, la tecnología, que ha permitido la proliferación de las imágenes, ahora se convierte también en el único medio de controlar y subyugar a esas mismas imágenes.

La convergencia entre la imagen y la pantalla da cuenta de este hecho. Las pantallas se multiplican interponiéndose entre nosotros y nuestro entorno. Son la conversión de la imagen en artefacto, su cuerpo. Se anteponen y se imponen al mundo externo con la prepotencia de lo luminoso, que indica siempre un más allá, una trascendencia, aunque, de hecho, no sean sino muros de luz que dejan al mundo en una oscuridad monocroma e inaccesible. "Se supone -aseveró Flusser- que las imágenes hacen accesible e imaginable el mundo para el hombre. Pero, incluso cuando lo hacen, se interponen entre el hombre y el mundo. Se supone que son mapas, y se convierten en pantallas» (13). Deleuze entendió, incluso, que este carácter de barrera de las imágenes forzaba al poder, no a ocultarnos la realidad, sino un aspecto de la imagen misma:

[...] nunca percibimos del todo lo que hay en la imagen, porque ella está hecha para eso (para que no percibamos todo, para que el tópico nos oculte la imagen...). ¿Civilización de la imagen? De hecho se trata de una civilización del tópico, donde todos los poderes tienen interés en ocultarnos las imágenes, no forzosamente en ocultarnos la misma cosa sino en ocultarnos algo en la imagen (36-7).

No es posible parar la generación de imágenes, la psicología moderna solo puede mantenerse ya en ellas, pero sí es posible aplicar sobre tales imágenes un dominio tan intenso, que dicha intervención sea más patente que la imagen misma. El goce de muchas de las imágenes digitales procede, por tanto, más del control ejercido sobre ellas que de ellas mismas. La imagen no es ya copia, representación o ventana, sino campo de batalla. Es soporte -por eso llega a coincidir con la pantalla- en el que se ejerce una gozosa potestad. Se puede llegar a pensar que tras el goce que supone este dominio late un cierto temor ante la nueva realidad que constituye el nivel de las imágenes. El posible miedo ante la expansión amenazante de este nivel, ante la inquietante multiplicación de las imágenes-pantalla, se contrarresta con una soberanía sobre los modos de producción de imágenes. Lo humano reconocible en ellas no viene dado ya por lo humano representado, sino por la capacidad de dominio y sometimiento de la que el ser humano es capaz sobre sus creaciones. El temor que la ciencia-ficción ha representado tantas veces respecto a la autonomía de las máquinas, se produce a un nivel inconsciente en el ámbito de las imágenes. 


\section{EL PARAÍSO ONTOGENÉTICO PERDIDO DE LA IMAGEN}

Esta autonomía de las imágenes, que las convierte en un nuevo y resistente velo de Maya, desplaza los asuntos sobre la verdad y el realismo de la representación a un segundo término ya que, como hemos apuntado, la relación de la imagen con lo real como referente no constituye ahora un rasgo definitorio suyo.

Aun así, las ideologías continúan recurriendo a las estéticas asociadas a sus posiciones, diferenciándose las facturas impecables y ultraperfeccionadas, propias de las imágenes producidas por los centros hegemónicos de poder, de las imágenes elaboradas en una imperfección provocada por los centros alternativos a aquellos poderes. Tales ideologías y tales estéticas fomentan el enfrentamiento entre la evasión a través de lo imaginario verosímil y el ideal de la autenticidad comprometida. Este enfrentamiento encierra la clásica oposición entre verosimilitud y verdad. Verdad como autenticidad en el sentido platónico contra la máxima aristotélica de la verosimilitud. Como escribe Borges en el cuento de El Aleph, «Deutsches Requiem»:

Se ha dicho que todos los hombres nacen aristotélicos o platónicos. Ello equivale a declarar que no hay debate de carácter abstracto que no sea un momento de la polémica de Aristóteles y Platón; a través de los siglos y latitudes, cambian los nombres, los dialectos, las caras, pero no los eternos antagonistas (90-1).

Las ambigüedades del realismo, que tantas reflexiones y discusiones ha desatado en la teoría del cine, proceden de su implicación en los dos ámbitos: en lo verdadero y en lo verosímil. Ahora, en el contexto de la búsqueda de hiperrealidad del cine digital, el término "realismo» se ha convertido en un referente aún más confuso e inasible de lo que ya era en la historia del cine analógico, más si consideramos lo que se ha consolidado como tópico desde La sociedad del espectáculo: la pérdida de lo real como referente de la imagen. Es cierto que la imagen sintética se aferra con más intensidad que la imagen analógica al ideal de lo verosímil y que, por ello, actualiza los criterios realistas; como dice Darley, «La síntesis digital de la imagen quizás constituye el ámbito en el que el objetivo estético del 'realismo' ha resultado más tenaz e influyente» (41), pero lo más significativo es que, en el contexto de la imagen digital sintética, la cuestión del realismo ha sido desplazada por la idea de vida: no se exige tanto la adecuación realista a una realidad, la impresión de realidad, como la impresión de vida. Se valora que personajes y mundos artificiales cobren, animándose, la consistencia de lo vital sin que la huella de lo real tenga que marcarles en ningún punto. No es propiamente realidad lo que se pide a las representaciones en el cine digital, sino vida e identidad. Esta es una de las razones que explica la progresiva importancia del cine de animación en los últimos años. «El espectáculo en general, como inversión concreta de la vida -había dicho también Debord-, es el movimiento autónomo de lo no vivo». Las nuevas imágenes toman como modelo a Prometeo y a Frankenstein antes que al Doppelgänger o doble. 
Esta vivificación no afecta solo a las figuras animadas, sino, fundamentalmente, a los entornos, a los espacios en los que se desarrolla la acción, que han pasado a convertirse en sistemas o en organismos de gran notoriedad. Esto no se aprecia solo en el nuevo cine de efectos digitales, que permite con mayor facilidad el sistematismo y la organicidad hasta el detalle ínfimo: la exquisitez alcanzada en la dirección artística de espacios en el cine mainstream desde los años noventa también da cuenta de ello. El historicismo es utilizado como pretexto para generar espacios de gran profusión visual en los que se exhibe la victoria sobre la representación. Ese rasgo de fidelidad histórica se extiende curiosamente a los mundos imaginarios, al tiempo que la hipertrofia visual de lo fantástico se involucra en las representaciones históricas. La diferencia entre historia y fantasía se hace casi irrelevante dentro de la propia imagen.

El mito histórico y el mito apócrifo se fusionan. Resulta sorprendente constatar cómo la creación de espacios míticos constituye un referente común en la integración progresiva de las tecnologías digitales en el seno del cine. Aun en las tramas más mundanas, una buena parte del cine digital ha acabado convirtiendo la imagenpantalla en un nuevo espacio mental cuya conquista se realiza mediante su absoluta reinvención. En la era digital, el espectador se convierte en un explorador cuyo ojo atraviesa espacios siempre vírgenes e inéditos, sean estos históricos o imaginarios. Tanto en la frialdad sintética de Tron (Steven Lisberger, Estados Unidos,1982), que exploraba el interior de la máquina prodigiosa, como en la conquista de mundos en planetas lejanos, ya sea en Avatar (James Cameron, Estados Unidos, 2009) o en los creados por George Lucas para las tres primeras partes de la saga Star Wars (Estados Unidos, 1999, 2002, 2005), el carácter novedoso y, por tanto, virgen de estos espacios es el que legitima su construcción. Esto explica también la rápida obsolescencia de estas arquitecturas efímeras, colonizadas al momento de ser observadas.

Lo paradójico es que, a pesar de esta conquista de espacios, el espectador es consciente de su carácter inalcanzable, de que solo se trata de una geografía abstracta destinada exclusivamente al goce visual pero que, a diferencia de los emplazamientos reales, como Nueva York o Grand Canyon, no podrá ser nunca habitada ni visitada de una forma auténtica. La fantástica tramoya no es más que un oasis que se desvanece al ser atravesado, un El Dorado cada vez más verosímil en su representación, pero progresivamente irreal en su materialidad.

La referencia a El Dorado, ese espacio mítico elucubrado en el encuentro con el nuevo continente no es trivial, porque nos sirve como eje de oposición entre dos concepciones opuestas frente a lo digital. Estos paraísos, si algo tienen en común entre sí, es precisamente su condición cibernética, en oposición a los remanentes de una imagen analógica en retroceso y que va convirtiendo a la idea de «realidad» en la gran expulsada del Edén audiovisual.

Esta recreación de los espacios de la imagen tiene también su contrapartida en el mundo industrial efectivo, en los lugares de producción reales (como si la institución cine hubiera consumado la trama de Matrix). El cambio hacia lo virtual está aceleran- 
do también la desaparición de los emplazamientos habitualmente identificados con la industria del cine, como es el caso de Hollywood. La antigua meca del cine ya no es el lugar habitual de trabajo de los equipos, y algunos de sus principales referentes hoy, como los estudios Weta o Pixar, se ubican muy lejos de este antiguo centro de control cinematográfico. La asequible recreación física de cualquier ambiente a través de lo tecnológico parece influir sobre la escasa importancia de la ubicación geográfica.

Uno de los aspectos más polémicos en el proceso de cambio hacia el paradigma digital proviene de su tendencia a homogeneizar procesos y procedimientos. En su afán por instituir un nuevo canon de los dispositivos digitales que privilegie una estética ilusionista y virtual de gran aparataje, centrada, como ya hemos dicho antes, en la simulación, los grandes conglomerados multimedia responsables de la industria del entretenimiento y el ocio vinculada a Hollywood han convertido, en palabras de Ángel Quintana, la búsqueda en pos del realismo en una gran quimera que está dejando de lado numerosas propuestas estéticas igualmente válidas (40).

\section{LA AUTENTICIDAD APUNTALADA. IMÁGENES CINEMATOGRÁFICAS DE AMÉRICA LATINA}

«Una imagen resulta hermosa no porque lo sea en sí... sino porque es el esplendor de lo auténtico» (cit. en Casetti 31). Esta conocida frase de Godard pierde vigencia en el ámbito de la imagen sintética. Dentro de los límites del cine digital no resulta sencillo oponer autenticidad a artificio, o descubrimiento a creación, porque ambas dimensiones están ya insertas en la esfera de lo imaginal. La imagen-pantalla ha absorbido todo referente, convirtiéndose en superficie privilegiada de la nueva percepción. Ella es mundo generado y generador.

Lo auténtico es, en la mayor parte de los casos, algo tan fingido como lo ficticio verosímil porque esa autenticidad también puede ser forjada, y lo ha en muchas ocasiones, por los centros hegemónicos de la producción cinematográfica. El poder institucional de Hollywood integra a la disidencia y la recupera, convirtiéndola en un género más de la extensa producción global. Esto ha sucedido frecuentemente con el cine independiente, con el cine europeo y, de una manera muy diferente y específica, con el latinoamericano.

Existe desde hace tiempo, pero especialmente en el nuevo siglo, un interés de las industrias norteamericanas y europeas por el cine latinoamericano. Este interés se ha manifestado en la progresiva consolidación del modelo de la coproducción internacional. Constituye un hecho significativo el que la mayor parte de las películas latinoamericanas desde los noventa sean coproducciones (a veces de hasta seis países), deslocalizadas económicamente aunque localizadas argumentalmente en América Latina. Brasil fue un país pionero en este sentido con las películas de Barreto y Babenco en los años setenta y, más tarde, con Walter Salles. En los últi- 
mos años, el cine del mexicano González Iñárritu pasa a formar parte incluso del mainstream norteamericano con coproducciones transatlánticas que canonizan esa deslocalización-localización, como se aprecia en Babel (Estados Unidos, México, Francia, 2006). Se extiende a nivel internacional un interés por producir películas latinoamericanas, con equipos, asuntos y espacios del centro y sur de América. En España, por ejemplo, América Latina es un horizonte que ha cobrado atractivo en las últimas décadas, y no de manera monolítica, sino en toda su diversidad de identidades y matices, aunque se concrete en una mayor implicación con la industria argentina.

Bajo esta inclinación late una cierta huida hacia lo auténtico por parte de las industrias cinematográficas predominantes, que identifica el cine latinoamericano con aquellos clichés de la imperfección y el realismo documentalista. La coproducción, como forma de participación, pero también de intervención, fuerza, en cierto modo, al cine de América Latina a conformarse a la imagen que de él se tiene desde fuera. Se le recluye en el espacio de la imagen analógica, como paraíso perdido que resiste al reino de las imágenes-pantalla, aunque, la intervención industrial internacional neutraliza aquella autenticidad ejerciéndola como mero estilo. Queda determinar si las potencias internas del cine latinoamericano oponen resistencia o no a esta reconstrucción artificial forzada desde el exterior. Nuestro objetivo concreto es analizar este aspecto en la producción de películas de animación y 3D, avanzadilla tecnológica y estética del cine digital.

No obstante, es preciso aclarar también que los territorios reales, las naciones y las comunidades efectivas no existen para la industria cinematográfica global sino como emblemas. El mismo «Hollywood» no es sino una marca bajo la que operan grandes corporaciones (Roig 151). El juego de las identidades, que se presuponen como algo ya dado, se transpone al ámbito del intercambio imaginario y simbólico de la industria global y eso se refleja en una industria deslocalizada y transnacional. En qué medida las identidades genuinas perviven bajo este nivel es algo que intentaremos apuntar en el ámbito latinoamericano.

El sistema económico mundializado fomenta la ilusión de lo diverso, ideal en el que se acoplan mutuamente la ansiedad de lo nuevo con el deseo de lo exótico. Como afirma Lazo, recogiendo el pensamiento de Foucault y de Žižek: «Pars pro totto, el sistema universal de dominio y explotación aprovecha lo particular para hacerse más fuerte. La identidad particular de grupos culturales, la imagen que les es inherente, es utilizada como 'sustituto contingente' de la 'batalla política' (ideológica) ya ganada de antemano de la 'universalidad hegemónica' del capitalismo» (66). Es preciso tener en cuenta, sin embargo, que en el régimen de la coproducción con la industria latinoamericana se implican lo público y lo privado, la política y la economía, a través de la intervención de las televisiones públicas y privadas. 


\section{MANIFIESTOS DEL NUEVO CINE E IDENTIDAD CINEMATOGRÁFICA LATINOAMERICANA EN LA ERA DIGITAL}

A pesar de la enorme distancia que nos separa del contexto en el que surge el llamado Nuevo Cine Latinoamericano, su influencia teórica y su estatus como marco de referencia sigue pesando, cincuenta años más tarde, sobre la mayoría de los países implicados, no solo por su significación histórica -constituye un período de indudable brillantez cinematográfica para muchos de sus protagonistas, especialmente para Brasil y Cuba-, sino porque una buena parte de sus presupuestos teóricos y programáticos siguen vigentes. Aun considerando los enormes avances sociales y políticos del continente, América Latina sigue constituyendo la región con mayores desigualdades económicas del mundo según un informe de las Naciones Unidas (Programa de las Naciones Unidas para el Desarrollo). Por otro lado, se alarga la enorme sombra de los Estados Unidos, un vecino ineludible al que tarde o temprano se acaba dirigiendo la mirada y cuya simple presencia justifica, al menos, una parte de las posiciones y derivas políticas que atenazan al continente. La amenaza del «imperio yanqui» no solo ha servido como excusa para justificar un retorno más o menos amplio de los gobiernos de izquierda a América Latina, sino que también ha valido, en algunos casos, para asentar posturas abiertamente "antiimperialistas». Bajo este paraguas dialéctico se entiende que el provocativo manifiesto Una estética del hambre, escrito por Glauber Rocha en 1965, siga teniendo cierta vigencia en el ideario artístico del continente.

Dejando incluso a un lado su ardor crítico y revolucionario, existen razones más o menos evidentes para proclamar una cierta vigencia de aquellos textos programáticos asociados a los diversos movimientos cinematográficos de la época, y para concederles una gran capacidad de premonición. No obviamos que su relectura desde el paradigma actual tergiversa la importancia del contexto y del espíritu, propios del momento en que fueron pronunciados, pero estos manifiestos, en cierto modo, sirven de puente entre una identidad labrada desde dentro del cine latinoamericano, y la situación contemporánea, que pretende definirlo también desde fuera. Algunos de los aspectos que hemos señalado ya en esta exposición pueden rastrearse en ellos, especialmente en el conocido texto Por un cine imperfecto, escrito por Julio García Espinosa en 1969 (63-77). En él se planteaba la posibilidad de un cine popular hecho por las propias masas en cuanto los condicionantes de inaccesibilidad tecnológica desaparecieran. Aun teniendo en cuenta el contexto postrevolucionario en el que se inserta el texto, con su transcripción al ámbito fílmico de las teorías marxistas de lucha de clases, resulta interesante comprobar cómo ha acabado cumpliéndose una buena parte de lo que en él se anunciaba, aunque, tal y como su autor confesaba quince años más tarde, en otro escrito, el pasmoso avance tecnológico del último cuarto del siglo xx , que se dirigía hacia un acceso más democratizado a la tecnología, le generaba paradójicamente una "sensación de impotencia» (8-9). En la actualidad, este acceso se ha consumado con el abaratamiento de la tecnología y la aparición 
de Internet, que han acabado configurando a YouTube como el primer gran depositario colectivo de la memoria de las primeras décadas del siglo xxi. Cuando Ángel Quintana afirma que «no existe ningún modelo de película más libre que el de las películas familiares, pero no existe ningún otro modelo más ligado a las convenciones de un cierto imaginario óptico que los múltiples formatos capturados por videocámaras familiares» (183-4), constata, en un contexto más amplio, la paradoja que ha terminado atribulando a García Espinosa. La tecnología ha abierto la producción audiovisual a las masas, pero queda por determinar en qué medida el nuevo ojo de la cámara digital -que, como dice Kaja Silverman, es también una pantalla (13570)- opera solo como un medio de la memoria, y en qué medida también el empleo que los usuarios hacen de esta tecnología, reproduciendo una manera de mirar y, por tanto, una ideología, no convierten a estos registros o creaciones audiovisuales en una intempestiva resonancia de aquel «cine reaccionario» que García Espinosa denunciaba en su manifiesto.

Cuando hablamos de cine digital -basándonos en los análisis de Roig (17395)-, hablamos de una doble dirección que define lo contradictorio de los nuevos medios tecnológicos: la que avanza hacia una producción con alto nivel de inversión y rendimiento económicos, y la que sirve a una expresión ajena al mercado. Es cierto que estas dos líneas tienden a separarse, pero no es menos cierto que constantemente juegan a superponerse y a retroalimentarse.

Dentro de la primera, que atañe a la industria del cine predominante tanto en sus registros de mayor difusión como en los de menos, los parámetros del paradigma digital han sido acogidos sin apenas reservas por todo tipo de realizadores, lo que explica su rápida asimilación y la desaparición igualmente veloz de los métodos de trabajo relacionados con el registro fotoquímico-David Lynch, por ejemplo, ha llegado a afirmar que, tras finalizar Inland Empire, para él «ya no hay vuelta atrás hacia la película cinematográfica» (cit. en Riambau 19)-. Sin embargo, el principal problema para muchos cineastas consiste en aceptar su aplicación tal y como la entiende Hollywood y sus empresas vinculadas. En este asunto, resulta manifiesto que el poso posrevolucionario del Nuevo Cine Latinoamericano mantiene aún elementos válidos para responder al modelo de cine blockbuster y para configurar, por tanto, respuestas articuladas en cada una de las diferentes cinematografías nacionales del continente.

\section{SUMISIÓN O RESISTENCIA: CINES DE ANIMACIÓN LATINOAMERICANOS}

Para comprobar esto nos centramos en la animación digital infográfica en Latinoamérica, por constituir éste uno de los sectores audiovisuales más definitorios del modelo de cine digital desarrollado por Hollywood desde la década de 1990. La animación contemporánea ha sabido aprovechar la importancia creciente del papel de los efectos especiales para convertirse en una parte autónoma y muy visible de ese nuevo Hollywood, que busca en la vivificación artificiosa una salida a la mortecina 
irrealidad de sus historias analógicas (no es exagerado afirmar que la vida de sus personajes de animación recientes es más briosa que la de los tipos de carne y hueso de las últimas décadas). Tomando en cuenta la enorme popularidad que este tipo de cine suscita actualmente y su creciente importancia económica -seis de las veinte películas más taquilleras de 2011 fueron de animación, y otros siete títulos incluían animación de personajes (Box Office Mojo)-, autores como Manovich han llegado a argumentar que la animación ha pasado de constituir casi una forma residual dentro de lo cinematográfico a redefinir los conceptos mismos del cine. Según Manovich, el cine digital, "forma particular de animación que usa la imagen real como uno de sus elementos»y, por tanto, determinado por los principios de la animación, ha hecho que el cine se convierta (o vuelva a convertirse) en un subgénero de la pintura (Manovich 5 y 2). Esta argumentación apunta demasiado lejos y se ajusta tan solo al cine digital de grandes efectos especiales, pero refleja el importante desplazamiento en la consideración de la animación dentro del debate teórico del cine y demarca el estatuto de los cines predominantes, estatuto del que debemos ser conscientes en un análisis del cine latinoamericano como ideología o contraideología.

El primer aspecto que llama la atención en el cine de animación 3D realizado en Latinoamérica es su tardía incorporación, sobre todo si se lo compara con lo sucedido en Europa o en Asia. Tras el estreno de Toy Story (John Lasseter, Estados Unidos, 1995), la primera película de animación infográfica de la historia del cine, la industria de la animación norteamericana tardó casi tres años en reaccionar, aunque, una vez superado el shock inicial, la técnica acabó desbancando en muy pocos años la posición dominante que el largometraje de animación dibujado había tenido hasta ese momento en el cine norteamericano (apellido autor número de página).

El primer largometraje de animación 3D latinoamericano se realizó en 2005, fecha de estreno de Piratas en el Callao (Eduardo Schuldt, Perú, 2005). La productora limeña Alpamayo Entertainment es la que introduce la técnica en el continente, y la que enseguida busca una continuidad con el estreno, un año más tarde, de Dragones: destino de fuego (Eduardo Schuldt, Perú, 2006) y en, 2008, de Valentino y el clan del can (David Bisbano, Perú). Poco después, Eduardo Schuldt realiza con la productora Dolphin Films El delfín: la historia de un soñador (Perú 2009). El hecho de que Perú, país con un volumen cinematográfico reducido en comparación con otras cinematografías latinoamericanas, fuera el único productor de animación 3D en América Latina hasta 2009, demuestra el desinterés inicial con el que fue recibida la animación tridimensional en la región. En su conjunto, los cuatro filmes peruanos, de una conceptualización técnica y cinematográfica aún exigua, traslucen una identidad cultural confusa, ya que en ellos los personajes y ambientes presentados cuentan con unos rasgos universales sobre los que luego afloran, injustificadamente a veces, detalles localistas. Por ejemplo, en Piratas en el Callao se recrea una serie de elementos históricos del Perú colonial de inicios del siglo XVII, pero el reducido nivel representacional de los espacios genera demasiadas ambigüedades para que 
el relato funcione bien en ese plano, lo que hace que el filme oscile continuamente entre la concreta determinación histórica y un relato genérico de aventuras infantiles. Los problemas de indefinición identitaria son también una constante del modelo de animación predominante, un modelo que parte de unos niveles de abstracción bastante elevados y que busca en lo multicultural ese quimérico afán por la diversidad al que aludíamos arriba. Pero, en el caso de los cines que siguen ese modelo sin pertenecer a la gran industria, la confusión de géneros y referencias socioculturales surge también por un interés, la mayor parte de las veces frustrado, de aunar lo global y lo local. En la base se encuentra una aceptación sin condiciones, una cierta sumisión, en definitiva, de este cine de animación infográfico a los modelos de más éxito que representa la industria norteamericana. Un caso ciertamente ridículo lo constituye el largometraje de animación español Planet 51 (Jorge Blanco, Javier Abad y Marcos Martínez, España, 2009), que ha dado pie a hablar de una tendencia a la pixarización, ya que en él sus productores se esforzaron «en emular los procesos de los competidores [norteamericanos], olvidando, hasta cierto punto, la diferenciación como valor estratégico", llevando así al filme a "caer en un americanismo más exacerbado que el de las propias producciones estadounidenses» (Martín 26 y 31).

La pixarización, o lo que es lo mismo, el deseo de emular o medirse con los grandes mogoles de la industria de la animación norteamericana, constituiría para las productoras meta y objetivo para otras empresas, de la misma manera que, para aquellas, el fin último es la asimilación y sobredimensión de la propio realidad. No se trata de un fenómeno nuevo, ya antes de la aparición de la animación infográfica, la animación producida por Walt Disney provocaba un efecto similar, y eso es debido en parte a que Disney «no solo derrotaba a la competencia, sino que la eliminaba, [...] su animación aparecía como la única posible. [...] Su trabajo alimentó la resistencia del público a aceptar propuestas alternativas» (Bendazzi 69). Al igual que Disney, pues, ahora Pixar (que es Disney), DreamWorks y el resto de nuevas majors de animación, crean en el público la percepción de que este estilo (dominante) es el único posible, y esto en ocasiones genera, en creadores independientes, un intenso sentimiento de oposición y de revancha que, en Latinoamérica, posee cierto eco indirecto de los Nuevos Cines Latinoamericanos. No está de más recordar que la más fuerte reacción contra el estilo Disney, la productora UPA, surgió precisamente de la disgregación creativa de la compañía tras las represalias por la huelga de 1941 y que, como señala Bendazzi, «la animación artística, en los Estados Unidos y en otros países, nació con la UPA» (133).

Este mismo rechazo hacia los estilos y las técnicas dominantes en animación es el que guía en primera instancia al autor peruano-chileno Jossie Malis, residente en Europa desde mediados de la década del 2000. Malis trabaja, como tantos autores de animación independientes, en el formato del cortometraje, y su obra más destacada hasta la fecha es la serie Bendito Machine (España 2006-2012), formada hasta el momento por cuatro cortometrajes independientes pero interrelacionados entre sí. A 
nivel argumental, cada episodio muestra el proceso de autodestrucción de sociedades a medio camino entre el tribalismo y la alta tecnología. Sin diálogos ni personajes estables, su estilo visual se basa en los diseños del teatro con marionetas de la isla de Java, una tradición a la que también remitía el cine de Lotte Reiniger. Una buena parte de la iconografía propia de Bendito Machine queda establecida por esta combinación entre el maquinismo industrial y las sociedades primitivas, que Malis lleva al ámbito estético de las culturas precolombinas, hasta el punto de conformar en conjunto una cosmogonía propia de densas ramificaciones mitológicas. A pesar de su marcada tecnofobia, Bendito Machine es a la vez una crítica y un producto característico de la era digital, ya que la serie ha sido producida por medios digitales y ha contado para su difusión exclusivamente con Internet.

Recuperando la línea de nuestra exposición, es solo a partir de 2009 cuando comienza a consolidarse una producción regular de largometrajes de animación 3D en otras partes de América Latina; en concreto, Brasil inicia su producción de animación digital con $\mathrm{O}$ grilo feliz e os insetos gigantes (Walbercy Ribas, Rafael Ribas, Brasil, 2009); Argentina estrena en 2010 sus tres primeros largometrajes de animación tridimensional, Plumíferos, aventuras voladoras (Daniel De Felippo, Gustavo Giannini, Argentina, 2010), seguida de la notable Cuentos de la selva (Liliana Romero, Norman Ruiz, Argentina, 2010) y de la coproducción con México e India Gaturro (Mariano Chiesa, Argentina, 2010); México estrena en 2011 sus dos primeros largometrajes de animación 3D, el largometraje infantil Don Gato y su pandilla (Norman Ruiz, Liliana Romero, Jorge Maestro, 2010) en coproducción con Argentina, y la fantasía religiosa El gran milagro (Bruce Morris, México, 2011). Cada uno de estos filmes demuestra, a su manera y con sutiles diferencias entre ellos, la homogeneización de la animación infográfica a nivel mundial, aunque, sin duda, Plumíferos es el título que más contradicciones ofrece.

Este filme, de rodaje azaroso y resultados ampliamente insatisfactorios, es reconocido como la primera producción realizada con Blender, un programa de creación de contenidos infográficos gratuito y basado en la filosofía de código abierto (opensource). Pero, a pesar de que el largometraje fuera subvencionado por la propia fundación encargada de su desarrollo, con una filosofía de trabajo más cercana a los planteamientos de Creative Commons y, por tanto, al menos teóricamente, al margen de los cánones de la gran industria del ocio, resulta paradójica su entrega a una concepción estereotipada, absolutamente plegada a los cánones frecuentados de la industria de la animación norteamericana. Plumíferos y, por tanto, Blender, acababan traicionando su condición de alternativas a los estándares existentes, convirtiéndose simplemente en software que compite por reemplazar a los principales referentes industriales.

Otro rasgo común a todo el cine digital, dominante o no, es su carácter de hibridación, su constante apertura a la fusión, aunque esta fusión no sea sino una forma de mantenerse dentro de los límites de lo mismo. Lo «híbrido es modelo y 
predisposición para llegar a ser y significar, salto, mutación» (La Ferla 131), de la misma manera que la tecnología actual habita en la nube (on the cloud), sin una ubicación física y en permanente estado beta. Un ejemplo de esto lo encontramos en el largometraje mexicano El gran milagro, en el que se parte de una operación de transcodificación genérica -emparentar la tradición del cine religioso mexicano con los medios de animación infográficos- que acaba desbordando los propios límites genéricos del original, al convertir la zozobra espiritual de los tres personajes principales en un enfrentamiento de carácter fantástico-épico con las fuerzas del mal, que intervienen con una presencia física en pantalla, haciendo convivir en el mismo ámbito referentes tan diversos como el metaverso de Second Life o la trilogía cinematográfica de El señor de los anillos (The Lord of the Rings, Peter Jackson, Nueva Zelanda-Estados Unidos, 2001-2003).

En el otro lado, en el de la resistencia, hemos señalado antes una cierta postura, la del autor independiente Jossie Malis, próximo a la irreverencia cartoon de Luis Nieto (Viñolo). Es una de las formas de resistencia porque existen también posiciones más parapetadas, menos expuestas y en la retaguardia, y posiciones de una crítica abierta. Este último es el caso del largometraje de Carlos Santa Los extraños presagios de León Prozak (Colombia 2010). Santa es uno de los pioneros de la animación experimental de Colombia, y miembro fundacional del colectivo Moebius Anima, al que también pertenecen autores como Cecilia Traslaviña y Ana María Caro. Aunque su filiación artística lo sitúe del lado de creadores de animación experimental como Norman McLaren o Walter Ruttmann, sus obras van más allá de la experimentación formal de estos, porque incorporan una abierta crítica social y artística. Los extraños presagios de León Prozak plantea la adaptación del mito fáustico a la realidad contemporánea colombiana. Al inicio del largometraje, el joven artista León Prozak pone su cabeza al servicio del diablo Mefisto Ritalini, lo que sirve a ambos personajes para enzarzarse en una discusión sobre la concepción contemporánea del arte y al autor como excusa para introducir una gran variedad estilística en el filme, que incluye técnicas tan dispares como la tinta sobre papel y acetato, la rotoscopia, la pintura y la arena sobre vidrio, el cut-out, el stop-motion, el dibujo digital, o la manipulación de imagen real. De forma no casual, a pesar de la gran abundancia de técnicas, el autor rechaza de plano la inclusión de animación digital en el filme, especialmente de infografía. Esta separación tan nítida entre medios artesanales y digitales se fundamenta en el convencimiento de que estas últimas son la máxima representación actual de un ideal de perfección. Sobre esta valoración de lo irregular, lo inacabado e imperfecto, el filme superpone todo un subtexto de crítica social que apunta al clima de violencia en Colombia, y que permite establecer las oportunas relaciones del filme de Santa con las preocupaciones ideológicas y sociales de los Nuevos Cines Latinoamericanos.

Esta breve descripción del panorama de la animación digital en América Latina muestra, a pesar del carácter novedoso y embrionario que esta aún posee, una serie 
de rasgos significativos que nos sirven para acercarnos a unas conclusiones sobre la asimilación o el rechazo de la imagen sometida por parte de cinematografías que no forman parte de la avanzadilla tecnológica.

\section{HACIA UNA CONCLUSIÓN ENTRE INCLUSIÓN Y DIALÉCTICA}

Efectivamente, en este examen de la breve historia de la animación digital en América Latina hemos hallado, bajo formas específicas, aspectos que señalábamos al principio de nuestra exposición. Por una parte, en la pionera producción peruana observamos el conflicto no resuelto de la relación entre identidades, el intento de reproducir los esquemas de éxito norteamericanos yuxtaponiendo aislados matices de la historia y el mito vernáculos. De la misma manera, en la reciente producción mexicana especialmente, el fenómeno de la hibridación diluye los intermitentes afanes identitarios en los síntomas de la tendencia global: la autorreferencialidad del cine dominante, con sus constantes guiños a la cultura de masas de otras épocas, sus cruces de géneros, etc. También, en el cine de animación digital argentino, la contradicción no asumida aparece en el uso de una tecnología asociada al software libre que se doblega a los presupuestos y a las formas del cine convencional. Pero, por otra parte, sobre todo en Colombia, localizamos una resistencia consciente a los modelos de la gran industria desde una revisión de los mitos populares y en clara filiación con los ideales de los Nuevos Cines Latinoamericanos.

Si leemos este trazado desde nuestra tesis principal, la del sometimiento de la imagen como símbolo de las sociedades avanzadas, en América Latina podemos hallar esa misma tendencia y también la opuesta. Ahora bien, ¿en qué medida esa tendencia a la imagen sometida se entronca con la tradición latinoamericana? Es decir, ¿el control sobre la imagen en el Sur procede del mismo desarrollo en las formas de mirar y de ver del Norte, o se trata simplemente de una asimilación de este por parte de aquel? ¿En qué medida también la oposición y la resistencia han identificado ese dominio sobre la imagen como una herramienta de poder de unas sociedades y mercados sobre otros?

Aunque este contraste entre asimilación y resistencia se produce también en otras regiones geográficas, su carácter es mucho más marcado en América Latina. Esto se debe, en parte, a una persistencia del mito popular -a la que contribuyen tanto la presencia foránea en las producciones cinematográficas latinoamericanas, que mantienen su afán por preservar una identidad desde fuera, como un movimiento de resistencia-, pero aquel contraste surge también de una cierta vigencia de los manifiestos cinematográficos de los años sesenta, que redefinieron una mitología cinematográfica forjada en las décadas anteriores y consolidaron una imagen del cine latinoamericano fuera de sus fronteras. Es decir, las potencias internas y externas confluyen para consolidar una identidad en la que el mito antiguo y el mito nuevo se asocian de alguna manera. 
No obstante, hay quienes que, como Deleuze, han intentado desenmascarar la supuesta conciencia de aquel cine revolucionario. De ser esto cierto, no sería tan marcada la diferencia entre la postura asimiladora y la repeledora, ya que en ambas estaría ausente una auténtica conciencia. Reproducimos aquí la cita de Deleuze, a pesar de su extensión y de estar escrita en 1985, porque en ella es posible reconocer la pervivencia del ideario de los Nuevos Cines y su contribución a la identidad del cine latinoamericano :

"[...] ya no hay 'línea general', es decir, evolución de lo Antiguo a lo Nuevo, o revolución que dé un salto del uno al otro. Hay más bien, como en el cine de América del Sur, una yuxtaposición o una compenetración de lo antiguo y lo nuevo que 'compone un absurdo', que toma 'la forma de la aberración» (Schwarz). Lo que reemplaza a la correlación de lo político con lo privado es la coexistencia hasta el absurdo de etapas sociales muy diferentes. De este modo, en la obra de Glauber Rocha, los mitos del pueblo, profetismo y bandidismo, son el envés arcaico de la violencia capitalista, como si el pueblo volviera y redoblara contra sí mismo, en una necesidad de adoración, la violencia que él sufre por otra parte (Dios y el diablo en la tierra del sol [Brasil, 1964]). La toma de conciencia está descalificada, bien sea porque se cumple en el aire como entre los intelectuales, bien sea porque está comprimida en un hueco [...]. ¿Qué queda entonces? El más grande cine ‘de agitación’ que se haya hecho nunca: la agitación ya no emana de una toma de conciencia, sino que consiste en 'poner todo en trance', el pueblo y sus amos, y la cámara misma, empujar todo a la aberración, para comunicar las violencias entre sí tanto como para hacer pasar el asunto privado a lo político, y el asunto político a lo privado (Tierra en trance [Brasil, 1967]). De ahí el singular aspecto que asume en Rocha la crítica del mito: no se trata de analizar el mito para descubrir su sentido o su estructura arcaicos, sino de referir el mito arcaico al «estado de las pulsiones en una sociedad perfectamente actual, el hambre, la sed, la sexualidad, la potencia, la muerte, la adoración» (289-90).

En la nueva resistencia latinoamericana al cine digital de animación dominante no se reconoce, esa agitación ajena a la conciencia que Deleuze atribuye a Rocha y a sus correligionarios. Se da más bien una avisada oposición a los modelos de la gran industria, un lúcido antagonismo. El reto de esta resistencia consiste en no incidir en una simple reacción formal recurriendo a los tópicos estilísticos asociados a lo auténtico, sino en hallar formas de expresión genuinas a través del nuevo medio y más allá de las ideologías supuestas (desde fuera) o autoimpuestas (desde dentro). Aunque, por otra parte, sí es cierto que esta resistencia tampoco se entrega a un análisis del mito y de su sentido sino, como en Rocha, a un «referir el mito arcaico al estado de las pulsiones en una sociedad perfectamente actual», tomando conciencia de la tecnología y del uso que la estética industrial dominante hace de ella para someter a las imágenes.

La imagen sometida es una tendencia asociada a los modos de percibir y de crear de las sociedades tecnológicamente avanzadas. Es una disposición socializada 
recogida por una industria muy sensible a las mentalidades y las percepciones de la mayoría, que posee, incluso, medios para captar y cuantificar esas percepciones, esos insights. Como propensión, pues, procede tanto de los que crean como de los que perciben, porque unos y otros se hallan insertos en la misma mentalidad. La gran industria, que busca el éxito en el número, consolida esta tendencia fomentando el modelo tecnológico-estético que más se ajusta a ella. Que el cine de animación hoy se esté convirtiendo en el eje de esa industria y en el núcleo de la definición del cine tiene que ver con esto porque, dentro del cine digital, la animación es la forma que permite un mayor dominio y control sobre la imagen, un mayor sometimiento de esta por medio de una tecnología patente, de una tecnología que ejerce de verdugo, o quizás, más bien, de gladiador forzado a reducir a su contrincante en el nuevo circo de las masas.

Que las industrias menos desarrolladas reproduzcan los modelos de las industrias más avanzadas es algo que ha ocurrido siempre. Cuando esto sucede, aquella tendencia de la que hablamos se propaga y se globaliza afectando a sociedades que la asimilan de una manera diferente, porque ahora el efecto crea la causa al remitir a ella; es decir, las formas asociadas a la imagen sometida, a su estética y a su estilo, ahora generan la tendencia a someter las imágenes. Esto ha sucedido en el cine de animación digital latinoamericano y en otros como el europeo, que han asimilado el modelo de la industria norteamericana, como hemos visto, pero, lo más característico del primero, y es esta la razón por la que nuestro análisis se ha dirigido a esa zona, ha sido su especial identificación con la resistencia a modelos predominantes.

No hemos hallado en este continente, sin embargo, una fuerza de resistencia tan amplia y consciente como se podría suponer, y hemos podido comprobar que la asimilación implantada ha sido más extensa, aunque pretendiera redimirse, en algunos casos, con referencias a la identidad local. Existe una cierta imagen disidente, como la que encontramos en Colombia, que parece ser tan consciente de sus mitos como del poder de la industria dominante. Esta resistencia (porque ante un dominio intenso cualquier diferencia termina configurándose como disidencia) mantiene la asociación entre arte e imperfección de la que hablara Arnheim en los años treinta (la imperfección hace al arte), aunque esta imperfección no es ya la que usualmente se asocia al cine social latinoamericano, sino la de la factura de las artes artesanales frente a las artes digitales.

Sucede también que, si el cine de la era audiovisual fomentó una desacralización de la imagen cinematográfica, como hemos señalado, algo que se agudiza aún más en la era digital, el cine de resistencia dentro de esta última parece buscar una nueva sacralidad de la imagen diferente de la del cine que llamamos clásico. Este intento de restitución del aura se plantea fundamentalmente como una abierta lucha contra los usos de la tecnología, en unos términos que vuelven a traer a primer plano las conocidas tesis de Benjamin de 1936. Esa lucha contra lo tecnológico se opera, como ha sucedido muchas veces antes, desde una vuelta a lo artístico, es decir, desde 
una vuelta a las formas del arte previas a la inserción de lo estético en lo masivo y lo tecnológico. Arte y tecnología, asociadas a la gran industria, se presentan como sendas inversas que dirigen los pasos respectivamente hacia un pasado y un futuro igualmente míticos.

\section{REFERENCIAS}

Adorno, Theodor W. Teoría estética. Trad. Jorge Navarro Pérez. Madrid: Akal, 2004. Medio impreso.

Arnau Roselló, Roberto. «Relaciones entre imagen y poder: de la apariencia al panoptismo. Conceptos de base». Fecha de ingreso: 16 de abril de 2012. <http://dx.doi. org/10.3239/9783640778409>. Sitio web.

Bazin, André. ¿Qué es el cine? Trad. de José Luis López Muñoz. Madrid: Rialp, 1966. Medio impreso.

Bendazzi, Giannalberto. Cartoons. 110 años de cine de animación. Madrid: Ocho y Medio, 2003. Medio impreso.

Borges, Jorge Luis. El Aleph. Madrid: Galaxia Gutenberg / Círculo de lectores, 1999. Medio impreso.

Box Office Mojo. Fecha de ingreso: 1 de abril de 1012. <http://boxofficemojo.com/yearly/ chart/?yr=2011>. Sitio web.

Calabrese, Omar. La era neobarroca. Trad. Anna Giordano. Madrid: Cátedra, 1989. Medio impreso.

Casetti, Francesco. Teorías del cine. Trad. de Pepa Linares. Madrid: Cátedra, 1994. Medio impreso.

Darley, Andrew. Cultura visual digital. Espectáculo y nuevos géneros en los medios de comunicación. Trad. Enrique Herrando y Francisco López. Barcelona: Paidós, 2002. Medio impreso.

Debord, Guy. La sociedad del espectáculo. Trad. José Luis Pardo. Valencia: Pre-Textos, 2003. Medio impreso.

Deleuze, Gilles. La imagen-tiempo. Estudios sobre cine 2. Trad. Irene Agoff. Barcelona: Paidós, 1987. Medio impreso.

Flusser, Vilém. Una filosofía de la fotografía. Trad. Eduardo Molina. Madrid: Síntesis, 2001. Medio impreso.

García Espinosa, Julio. «Por un cine imperfecto». Hojas de cine: testimonios y documentos del Nuevo Cine Latinoamericano: Volumen III. Ed. Fundación Mexicana de Cineastas. México: UNAM, 1988. Número de páginas del capítulo. Medio impreso.

--. «Meditations on Imperfect Cinema... Fifteen Years Later». New Latin American Cinema. Volume One: Theory, Practices and Transcontinental Articulations. Comp. Michael Martin. Detroit: Wayne State University Press, 1997. Medio impreso.

La Ferla, Jorge. Cine (y) digital. Aproximaciones a posibles convergencias entre el cinematógrafo y la computadora. Buenos Aires: Manantial, 2009. Medio impreso. 
Lazo, Pablo. «La perversión semántica de las imágenes en una sociedad multicultural». Sociedades icónicas. Historia, ideología y cultura en la imagen. Coord. Diego Lizarazo. México: Siglo xxi, 2007. Medio impreso.

Manovich, Lev. «What is digital cinema?». Fecha de ingreso: 18 de abril de $2012<$ http:// www.manovich.net/TEXT/digital-cinema.html>. Sitio web.

Martín Núñez, Marta. «Planet 51 o la pixarización de la industria de animación española». L'Atalante: revista de estudios cinematográficos 10 (2010). 26-31. Medio impreso.

Münsterberg, Hugo. Hugo Münsterberg on film. The Photoplay: A Psychological Study and Other Writings. Ed. Allan Langdale. Nueva York: Routledge, 2002. Medio impreso.

Programa de las Naciones Unidas para el Desarrollo. Fecha de ingreso: 17 de abril de 2012: <http://bit.ly/RpFWpR>. Sitio web.

Quintana, Àngel. Después del cine. Imagen y realidad en la era digital. Barcelona: Acantilado, 2011. Medio impreso.

Reuters. ABC News. «Disney Western cartoon end of the hand-drawn breed». Fecha de ingreso: 18 de abril de 2012: <http://bit.ly/qrYbHj>.- Sitio web.

Riambau, Esteve: Hollywood en la era digital. Madrid: Cátedra, 2011. Medio impreso.

Roig, Antoni. Cine en conexión. Producción industrial y social, en la era 'cross-media'. Barcelona: UOC, 2009. Medio impreso.

Silverman, Kaja. El umbral del mundo visible. Trad. de Alfredo Brotons. Madrid: Akal, 2009. Medio impreso.

Stam, Robert. Teorías del cine. Trad. Carles Roche. Barcelona: Paidós, 2001. Medio impreso.

Viñolo Locuviche, Samuel. «Carlitopolis o el escamoteo de un ratón. La relectura del cartoon contemporáneo desde el cine de los orígenes». Con A de Animación. Fecha de ingreso: 18 de abril de 2012: <http://bit.ly/128ENos>. Sitio web. 